\title{
Identifikasi Pemborosan Aktivitas di Lantai Produksi PSR Menggunakan Process Activity Mapping dan Waste Assessment Model
}

\author{
Yulinda Uswatun Kasanah ${ }^{1 *}$, Pratya Poeri Suryadhini ${ }^{2}$ \\ 1 Program Studi Teknik Logistik, Fakultas Rekayasa Industri dan Desain, ITTelkom Purwokerto \\ ${ }^{2}$ Program Studi Teknik Industri, Fakultas Rekayasa Industri, Universitas Telkom \\ Email: yulinda@ittelkom-pwt.ac.id; pratya@telkomuniversity.ac.id
}

Artikel masuk : 23-09-2021

Artikel direvisi : 09-10-2021

Artikel diterima : 24-10-2021

*Penulis Korespondensi

\begin{abstract}
Abstrak -- Salah satu produsen ban terbesar di Indonesia dalam proses produksinya memiliki beberapa family produk seperti Passenger Tires, Commercial Tires, dan Industrial Tires. Passenger Tires atau PSR merupakan family produk dengan penjualan terbesar, akan tetapi dalam perkembangannya terdeteksi adanya penurunan performa produksi yang mempengaruhi optimalisasi penjualan perusahaan. Berdasarkan studi pendahuluan teridentifikasi adanya beberapa aktivitas pemborosan di lini produksi ban PSR. Mapping aktivitas bertujuan untuk menemukan jenis waste yang tepat pada setiap departemen produksi maupun workstation. Mapping dilakukan dengan menggunakan diagram Swimlane dan Process Activity Mapping (PAM). Hasil mapping mengidentifikasi aktivitas yang tidak memberikan nilai tambah dengan persentase aktivitas sebesar 48\%. Waste assessment model (WAM) dipakai untuk menentukan peringkat seven waste. Dari hasil analisis dengan menggunakan metode WAM diperoleh tiga waste kritis utama yaitu waiting, motion, dan overproduction dengan proporsi masing-masing waste sebesar $22 \%, 18 \%$, dan $16 \%$. Setelah diketahui waste kritis maka dilakukan analisis akar masalah penyebab waste dengan menggunakan fishbone chart diagram dan root cause analysis.
\end{abstract}

Kata kunci: Pemborosan; Process Activity Mapping; Seven Waste; Waste Assessment Model

\begin{abstract}
One of the largest tire manufacturers in Indonesia in its production process has several product families such as Passenger Tires, Commercial Tires, and Industrial Tires. Passenger Tires or PSR is a family of products with the largest sales. Still, in its development, it was detected that there was a decrease in production performance that affected the optimization of the company's sales. Based on the preliminary study, several wasteful activities were identified in the PSR tire production line. Activity mapping aims to find the right type of waste in each production department and workstation. Mapping is done using Swimlane diagrams and Process Activity Mapping (PAM). The mapping results identify activities that do not provide added value with a percentage of activities of $48 \%$. The waste assessment model (WAM) is used to determine the ranking of the seven wastes. From the analysis results using the WAM method, three main critical wastes are obtained, namely waiting, motion, and overproduction, with the proportions of each waste being $22 \%, 18 \%$, and $16 \%$. After knowing the critical waste, the root cause analysis of the waste is carried out using a fishbone chart diagram and root cause analysis.
\end{abstract}

Keywords: Waste; Process Activity Mapping; Seven Waste; Waste Assessment Model

\section{PENDAHULUAN}

Pertumbuhan pasar otomotif di Indonesia seiring berjalannya waktu semakin menunjukan adanya perkembangan yang signifikan. Industri ban mobil merupakan salah satu komoditi agroindustri otomotif yang berorientasi ekspor yang memberikan kontribusi cukup besar terhadap devisa negara. Salah satu produsen ban terbesar di Indonesia dalam proses produksinya memiliki beberapa family produk seperti 
Passenger Tires, Commercial Tires, dan Industrial Tires. Dari family produk tersebut dapat diketahui bahwa perusahaan memiliki banyak target pasar, mulai konsumen pengguna mobil penumpang, konsumen pengguna angkutan umum, konsumen pengguna kendaraan untuk industri, hingga konsumen pengguna kendaraan pertanian.

Departemen Passanger Radial (PSR) merupakan departemen yang memproduksi ban mobil untuk kendaraan pribadi atau mobil penumpang. Seperti Ecopia, Turanza, dan Techno. Dalam memproduksi produk-produk tersebut, terdapat beberapa kendala yang berdampak perusahaan tidak dapat menyelesaikan order tepat waktu. Salah satu cara dalam melihat performansi perusahaan dalam memenuhi order pelanggan adalah dengan membandingkan parameter output produksi dengan demand konsumen (Frandson \& Tommelein, 2014).

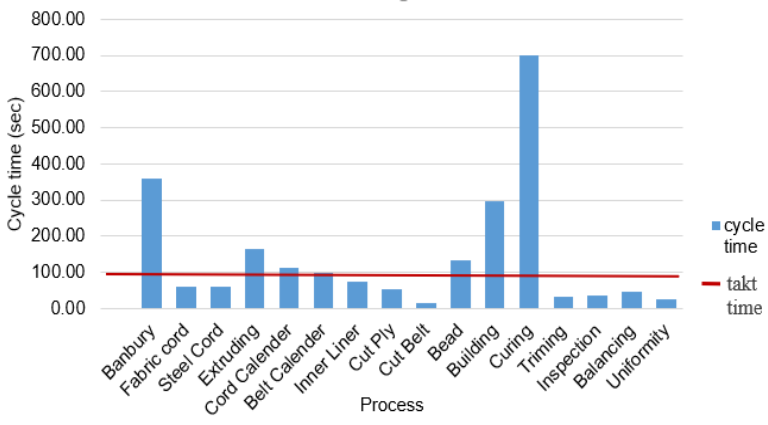

Gambar 1. Perbandingan Takt Time dengan Cycle Time

Gambar 1 menunjukkan perbandingan takt time dan cycle time pada lini produksi ban PSR. Dimana takt time merupakan waktu yang dibutuhkan untuk memproduksi satu unit produk berdasarkan demand konsumen (Linck \& Cochran, 1999). Lini produksi ban PSR dimulai dari tahap material preparation yang terdiri dari pembuatan fabric cord dan steel cord pada departemen Bunbury, kemudian component processing yang terdiri dari proses extruding, calendering, dan cutting yang menghasilkan material ply, dan terdapat juga proses machining yang di dalamnya terdapat dua proses utama yaitu building dan curing yang menghasilkan green tire, dan tahap terakhir merupakan tahap inspection.

Perhitungan takt time diperoleh dengan membandingkan demand konsumen dengan available time perusahaan dalam satu shift. Dimana demand konsumen sebesar 220 unit per shift dan available time sebesar 18000 detik per shift maka dapat diperoleh takt time sebesar 120 detik/unit. Perbandingan cycle time dan takt time terbesar yaitu terjadi pada bagian curing karena cycle time pada bagian curing melebihi waktu takt time. Setelah dilakukan studi pendahuluan untuk mengetahui dugaan awal faktor-faktor penyebab keterlambatan dengan cara melakukan observasi dan wawancara kepada pihak yang bersangkutan seperti operator dan manajer produksi maka diperoleh faktor penyebab terjadinya keterlambatan produksi adalah adanya beberapa aktivitas pemborosan yang terjadi pada lantai produksi PSR.

Proses observasi menggunakan metode Process activity mapping (PAM) dan Waste Assessment Model (WAM) pada lantai produksi PSR untuk mengetahui persentase waste terbesar atau waste dominan. Metode WAM sendiri dapat digunakan dapat digunakan untuk mengidentifikasi peringkat waste dalam suatu proses produksi (Pomalia et al., 2020) dengan melakukan assessment menggunakan tools seperti Waste Relationship Matrix (WRM) dan Waste Assessment Questionnaire (WAQ) (Ali et al., 2015). Ketika waste dominan sudah teridentifikasi maka diharapkan akan mempermudah perusahaan untuk menentukan langkahlangkah lanjutan dalam meminimalisir waste sehingga dapat meningkatkan performansi lini produksi PSR.

Penelitian-penelitian terdahulu yang menggunakan metode PAM dan WAM untuk mengidentifikasi waste pada lini produksi perusahaan manufaktur otomotif telah sukses diterapkan seperti pada penelitian Jasti \& Sharma (2014), Martha \& Arvianto (2018), dan Isnain (2017). Akan tetapi ketiga penelitian tersebut hanya berfokus pada satu departemen produksi saja, sedangkan dalam penelitian ini berfokus pada keseluruhan lini produksi ban PSR yang terdiri dari beberapa departemen. Tujuan dari penelitian ini adalah untuk mengidentifikasi waste dominan pada lantai produksi ban PSR sehingga dapat diketahui akar masalah penyebab terjadinya penurunan performansi perusahaan dalam memenuhi order pelanggan.

\section{METODE PENELITIAN}

Metode yang digunakan dalam penelitian ini merupakan gabungan antara dua metode, yaitu metode untuk mapping tools dan metode waste assessment. Kedua tools ini digunakan untuk mengidentifikasi waste yang terjadi dan mendefinisikannya ke dalam 7 waste. Pencarian jenisjenis waste pada proses produksi dilakukan setelah pengamatan langsung. Pencarian jenis waste disesuaikan dengan studi literatur dan studi menggunakan Waste Assessment Model (WAM). Sedangkan mapping tools yang digunakan adalah Process activity mapping (PAM). 
Tahap pertama yang dilakukan untuk mengidentifikasi waste awal adalah dengan melakukan studi literatur dan juga melakukan observasi langsung. Pengamatan secara langsung dilakukan dengan mengamati dan mencatat setiap aktivitas produksi pada masingmasing workstation pada lantai produksi ban PSR.

Tahap kedua setelah diperoleh data aktivitas lantai produksi ban PSR, berupa waktu siklus dan aliran material, maka dilakukan mapping awal dengan menggunakan diagram swimlane untuk melihat aliran material yang lebih detail (Jeyaraj et al., 2014). Setelah itu, dilakukan observasi lanjutan untuk mengamati aktivitas produksi secara keseluruhan, sehingga dapat dibuat mapping aktivitas proses produksi dengan menggunakan PAM.

Untuk mendapatkan waste yang lebih detail (sesuai dengan seven waste) maka dilakukan kalkulasi waste pada setiap workstation dengan menggunakan Waste assessment model (WAM). Dengan adanya WAM peringkat untuk masingmasing waste dapat diidentifikasi (Robecca et al., 2020). Setelah pemborosan terdefinisi maka langkah selanjutnya adalah menentukan akar masalah dengan menggunakan fishbone chart. Jika fishbone chart belum menjawab akar masalah dari pemborosan terpilih maka dilakukan identifikasi 5 whys. Tahap terakhir adalah tahap penarikan kesimpulan dan saran terhadap penelitian yang dilakukan.

\section{HASIL DAN PEMBAHASAN}

\section{Deskripsi Kerja dan Lantai Produksi}

Secara umum proses produksi ban PSR melalui 4 tahapan proses utama yaitu material preparation, component processing, machining, dan inspection (Gambar 2). Material utama yang digunakan untuk pembuatan ban PSR adalah rubber bales yaitu berupa natural rubber, synthetic rubber, carbon, aromatic oil, chemical, dusting, dan sheet rubber. Proses preparation terdapat proses pencampuran pada departemen bunbury, dan proses pembuatan fabric cord dan steel cord.

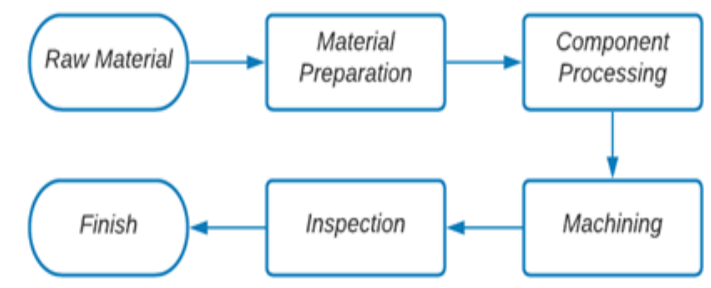

Gambar 2. Aliran Proses Produksi Ban PSR

Komponen processing mempunyai proses extruding yang membuat hasil adonan karet dari bunburry menjadi tread dan sidewall. Terdapat juga proses calendering (pembuatan material ply, steel belt, JLB, cap ply, dan Inner liner), cutting (proses lanjutan dari mesin callender untuk membuat Ply), dan Bead (pembuatan bead wire). Proses machining merupakan proses inti dalam pembuatan ban PSR dimana terdapat dua tahap proses utama yaitu proses building dan proses curing, dari kedua proses tersebut dihasilkan ban setengah jadi atau Green Tire.

\section{Process activity mapping}

Process activity mapping (PAM) digunakan untuk memetakan proses produksi yang terjadi dan menganalisis pemborosan (waste). Selain itu alat ini merupakan kunci dalam melakukan detailed mapping untuk proses pemesanan. Proses ini juga dapat digunakan untuk mengidentifikasi lead time, aliran fisik dan aliran material di dalam pabrik maupun diluar pabrik pada rantai logistik (Taylor \& Hines, 2000). PAM dibuat berdasarkan proses dan waktu yang dialami oleh sebuah produk dimulai dari raw material hingga proses penyimpanan produk jadi pada bagian warehouse. Proses produksi pembuatan ban PSR radial digambarkan pada Tabel 1 yang memiliki proses operasi, transportasi, inspeksi, storage, dan delay.

Tabel 1. Process Activity Mapping Produksi Ban PSR

\begin{tabular}{|c|c|c|c|c|c|}
\hline Deskripsi Aktivitas & $\begin{array}{l}\text { Mesin/ } \\
\text { Alat } \\
\text { Bantu }\end{array}$ & $\begin{array}{c}\text { Jarak } \\
(\mathrm{m})\end{array}$ & $\begin{array}{l}\text { Waktu } \\
(\mathbf{s})\end{array}$ & $O \quad T$ I $D$ & $\begin{array}{c}\text { NVA/ } \\
\text { VA// } \\
\text { NNVA }\end{array}$ \\
\hline \multicolumn{6}{|l|}{ menempatkan } \\
\hline $\begin{array}{l}\text { compound kedalam } \\
\text { pendingin } \\
\text { menunggu }\end{array}$ & Pendingin & 1 & 11 & & NNVA \\
\hline \multicolumn{6}{|l|}{$\begin{array}{l}\text { pendinginan } \\
\text { compund }\end{array}$} \\
\hline $\begin{array}{l}\text { menggulung } \\
\text { compound }\end{array}$ & $\begin{array}{l}\text { BB } \\
\text { dusting }\end{array}$ & & 9 & & VA \\
\hline \multicolumn{6}{|c|}{$\begin{array}{l}\text { menempatkan } \\
\text { compound pada rak Rak WIP }\end{array}$} \\
\hline $\begin{array}{l}\text { meletakkan } \\
\text { compound pada } \\
\text { inventory F/G } \\
\text { Bunbury }\end{array}$ & Forklift & 3 & 35 & & NNVA \\
\hline mengambil cement & & 1 & 23 & & NNVA \\
\hline $\begin{array}{l}\text { meletakkan } \\
\text { compound dan } \\
\text { cement }\end{array}$ & & & 13 & & VA \\
\hline \multirow{2}{*}{$\begin{array}{l}\text { proses tread } \\
\text { extruder } \\
\text { meletakkan tread } \\
\text { radial ke dalam } \\
\text { kereta cutting }\end{array}$} & $\begin{array}{l}\text { Single } \\
\text { Tuber } 8 "\end{array}$ & & 164 & & VA \\
\hline & conveyor & 0,5 & 12 & & NNVA \\
\hline \multirow{4}{*}{$\begin{array}{l}\text { meletakkan tire } \\
\text { pada rak } \\
\text { mengirim tire pada } \\
\text { warehouse produk } \\
\text { jadi }\end{array}$} & $:$ & $:$ & $:$ & $:::::$ : & $:$ \\
\hline & Forclift & & & & NNVA \\
\hline & Forclift & & & & NNVA \\
\hline & Total & 109,5 & 4659 & 20262410 & \\
\hline
\end{tabular}


Tabel 2. Ringkasan PAM

\begin{tabular}{lcc}
\hline \multicolumn{1}{c}{ Aktivitas } & Jumlah & Waktu (detik) \\
\hline Operation & 20 & 2400 \\
Transport & 26 & 923 \\
Inspection & 2 & 44 \\
Storage & 4 & 232 \\
Delay & 10 & 1060 \\
Total & $\mathbf{6 2}$ & $\mathbf{4 6 5 9}$ \\
\hline \multicolumn{1}{c}{ Klasifikasi } & Jumlah & Waktu (detik) \\
\hline VA & 20 & 2400 \\
NVA & 10 & 1060 \\
NNVA & 32 & 1199 \\
Total & 62 & 4659 \\
\hline \multicolumn{2}{c}{ Value Ratio } & $\mathbf{0 , 5 2}$ \\
\hline
\end{tabular}

Tabel 3. Ringkasan Analisis PAM

\begin{tabular}{|c|c|c|c|}
\hline $\begin{array}{c}\text { Jenis } \\
\text { Aktivitas }\end{array}$ & $\begin{array}{c}\text { Jumlah } \\
\text { Aktivitas }\end{array}$ & $\begin{array}{l}\text { Total } \\
\text { Waktu } \\
\text { Aktivitas } \\
\text { (detik) }\end{array}$ & Analisis \\
\hline Operation & $\begin{array}{c}20 \\
(32,2 \%)\end{array}$ & $\begin{array}{c}2400 \\
(51,5 \%)\end{array}$ & $\begin{array}{l}\text { Aktivitas operasi } \\
\text { merupakan aktivitas yang } \\
\text { value added, sehingga } \\
\text { yang perlu dijaga adalah } \\
\text { konsistensi proses. }\end{array}$ \\
\hline Transport & $\begin{array}{c}26 \\
(41,9 \%)\end{array}$ & $\begin{array}{c}923 \\
(19,8 \%)\end{array}$ & $\begin{array}{l}\text { Jumlah aktivitas } \\
\text { transportasi cukup banyak } \\
(41,9 \%) \text {. Hal ini diperlukan } \\
\text { adanya beberapa kali } \\
\text { proses handling namun } \\
\text { dengan jarak yang relatif } \\
\text { pendek dan adanya } \\
\text { pengambilan material pada } \\
\text { WIP proses sebelumnya. }\end{array}$ \\
\hline Inspection & 2 (3,3\%) & $\begin{array}{c}44 \\
(0,94 \%)\end{array}$ & $\begin{array}{l}\text { Terdapat } 2 \text { proses inspeksi } \\
\text { dengan total waktu yang } \\
\text { dibutuhkan } 44 \text { detik }\end{array}$ \\
\hline Storage & $4(6,4 \%)$ & $\begin{array}{c}232 \\
(4,98 \%)\end{array}$ & 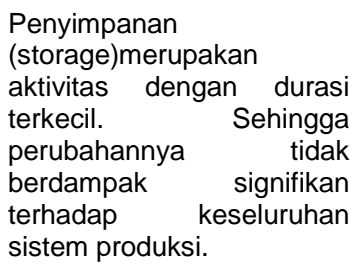 \\
\hline Delay & $\begin{array}{c}10 \\
(16,1 \%)\end{array}$ & $\begin{array}{c}1060 \\
(22,7 \%)\end{array}$ & $\begin{array}{l}\text { Delay disebabkan karena } \\
\text { adanya perbedaan cycle } \\
\text { time antar proses baik } \\
\text { berupa komponen maupun } \\
\text { manpower yang menunggu } \\
\text { proses atau melakukan } \\
\text { proses seperti setup time } \\
\text { yang terlalu lama seperti } \\
\text { pada workstation curing } \\
\text { dengan delay sebesar } 610 \\
\text { detik. }\end{array}$ \\
\hline
\end{tabular}

Berdasarkan PAM yang telah dibuat pada Tabel 1 maka dapat dibuatkan tabulasi ringkasan perhitungan dan persentase PAM (Tabel 2). Nilai value ratio untuk proses produksi pembuatan ban PSR adalah sebesar 0,52 atau $52 \%$. Value ratio merupakan nilai perbandingan antara aktivitas yang memberikan nilai tambah dengan keseluruhan aktivitas (Jasti \& Sharma, 2014).

Berdasarkan hasil evaluasi aktivitas produksi ban PSR dengan menggunakan PAM maka diperoleh ringkasan analisis hasil evaluasi PAM Ban PSR seperti pada Tabel 3. Hasil analisis PAM menunjukkan waste dengan waktu terbesar yaitu waste delay, dengan waktu delay sebesar 1060 detik dan waktu delay terbesar adalah pada aktivitas green tire yang menunggu untuk di curing.

\section{Waste Assessment Model}

Waste assessment model merupakan suatu model yang dikembangkan untuk menyederhanakan pencarian dan permasalahan waste dan mengidentifikasi eliminasi waste. Model ini menggambarkan hubungan antar seven waste $(\mathrm{O}$ : Overproduction, P: Processing, I: Inventory, T: Transportation, D: Defects, W: Waiting, dan M: Motion) (Rawabdeh, 2005).

\section{Waste Relationship Matrix}

Pengumpulan data dilakukan dengan cara diskusi dan menyebarkan kuesioner pembobotan kepada satu orang manager produksi, satu orang supervisor produksi, dan dua orang operator mesin bunbury dan mesin curing. Diskusi dilakukan untuk menyatukan persepsi tentang pemahaman terhadap waste dan keterkaitan antar waste. Penyebaran kuesioner dilakukan untuk mendapatkan bobot dari waste. Kemudian data diolah dengan menggunakan metode Waste Relationship Matrix (WRM) dimana WRM merupakan matrix yang digunakan untuk menganalisa kriteria pengukuran (Amrina \& Lubis, 2017). Baris pada matrix menunjukan efek suatu waste tertentu terhadap enam waste lainnya. Sedangkan kolom pada matriks menunjukan waste yang dipengaruhi oleh waste lainnya.

Tabel 4. Waste Relationship Matrix

\begin{tabular}{llllllll}
\hline & O & I & D & M & T & P & W \\
\hline O & A & A & 0 & U & 0 & X & E \\
I & U & A & 0 & 0 & A & X & X \\
D & 0 & U & A & E & U & X & I \\
M & U & U & A & A & X & I & E \\
T & 0 & 0 & X & X & A & X & I \\
P & I & 0 & X & 0 & X & A & 0 \\
W & E & 0 & 0 & E & E & X & A \\
\hline
\end{tabular}

Berdasarkan Tabel 4 dapat diketahui bahwa jenis konversi keterkaitan antar waste yang paling sering muncul adalah nilai $O$ dimana nilai $O$ menunjukkan bahwa keterkaitan antar waste bersifat ordinary closeness atau keterikatan antar wastenya bersifat sedang. Sedangkan untuk nilai A mengartikan bahwa keterkaitan antar waste 
bersifat absolutely necessary atau sangat terikat, untuk nilai $\mathrm{E}$ berarti keterkaitan antar waste bersifat especially important, untuk nilai I keterkaitan antar waste bersifat Important, untuk bersifat unimportant, dan untuk nilai X berarti tidak ada keterkaitan antara waste yang satu dengan waste yang lain.

\section{Waste Relationship Value}

Untuk penyederhanaan matrix kemudian dikonversikan ke dalam bentuk persentase (Tabel 5). Waste relationship matrix dikonversikan ke dalam angka dengan acuan $A=10, E=8, I=6, O=4$, $\mathrm{U}=2$, dan $\mathrm{X}=0$ (Rawabdeh, 2005).

Tabel 5. Waste Relationship Value

\begin{tabular}{cccccccccc}
\hline $\mathbf{F} / \mathbf{T}$ & $\mathbf{O}$ & $\mathbf{I}$ & $\mathbf{D}$ & $\mathbf{M}$ & $\mathbf{T}$ & $\mathbf{P}$ & $\mathbf{W}$ & Skor & $\%$ \\
\hline $\mathbf{O}$ & 10 & 10 & 4 & 2 & 4 & 0 & 8 & 38 & $16 \%$ \\
$\mathbf{I}$ & 2 & 10 & 4 & 4 & 10 & 0 & 0 & 30 & $13 \%$ \\
$\mathbf{D}$ & 4 & 2 & 10 & 8 & 2 & 0 & 6 & 32 & $14 \%$ \\
$\mathbf{M}$ & 2 & 2 & 10 & 10 & 0 & 6 & 8 & 38 & $16 \%$ \\
$\mathbf{T}$ & 4 & 4 & 0 & 0 & 10 & 0 & 6 & 24 & $10 \%$ \\
$\mathbf{P}$ & 6 & 4 & 0 & 4 & 0 & 10 & 4 & 28 & $12 \%$ \\
$\mathbf{W}$ & 8 & 4 & 4 & 8 & 8 & 0 & 10 & 42 & $18 \%$ \\
Skor & 36 & 36 & 32 & 36 & 34 & 16 & 42 & 232 & $100 \%$ \\
\hline$\%$ & $16 \%$ & $16 \%$ & $14 \%$ & $16 \%$ & $15 \%$ & $7 \%$ & $18 \%$ & $100 \%$ & \\
\hline
\end{tabular}

Pembobotan dari tiap baris dan kolom dari WRM ditotal untuk melihat skor yang menggambarkan efek atau pengaruh dari satu waste terhadap waste yang lain. Berdasarkan matrix relationship nilai from terbesar terdapat pada Waiting, Operation, Inventory, dan Motion. Hasil pembobotan dengan matrix relationship akan menjadi inputan untuk menjadi nilai awal dalam perhitungan Waste Assessment Questionnaire. Dengan menggunakan WAQ maka akan dilakukan pengukuran peringkat waste.

\section{Waste Assessment Questionnaire}

Langkah pertama dalam melakukan WAQ adalah dengan mengelompokkan dan menghitung jumlah pertanyaan $(\mathrm{Ni})$ dalam kuesioner sesuai dengan jenis pertanyaan. Dalam hal ini terdapat 39 pertanyaan yang diajukan kepada narasumber. Narasumber di sini merupakan seorang manajer produksi dan tiga supervisor masing-masing dari bagian Bunbury, Curing, dan Inspection.

Langkah selanjutnya yaitu menghitung jumlah skor (Sj) dan frekuensi (Fj) dari tiap jenis waste (Tabel 6). Perhitungan awal dilakukan dengan membagi nilai awal tiap baris dengan jumlah pertanyaan yang telah dikelompokkan untuk menghilangkan efek variasi pada setiap pertanyaan. Setelah ditemukan nilai $\mathrm{Sj}$ dan $\mathrm{Fj}$ pada masing-masing baris, maka dihitung total skor (sj) dan frekuensi (fj) untuk setiap waste (Tabel 7). Hasil kuesioner WAQ tersebut menjadi bobot yang kemudian dikalikan dengan nilai awal setiap baris.

Tabel 6. Hasil Perkalian Pembobotan dengan Jumlah Pertanyaan

\begin{tabular}{ccccccccc}
\hline No & $\mathbf{N i}$ & $\mathbf{O}$ & $\mathbf{I}$ & $\mathbf{D}$ & $\mathbf{M}$ & $\mathbf{T}$ & $\mathbf{P}$ & $\mathbf{W}$ \\
\hline 1 & 4 & 2.5 & 2.5 & 1 & 0.5 & 1 & 0 & 2 \\
2 & 3 & 0.67 & 3.33 & 1.33 & 1.33 & 3.33 & 0.00 & 0.00 \\
3 & 3 & 1.33 & 0.67 & 3.33 & 2.67 & 0.67 & 0.00 & 2.00 \\
4 & 3 & 1.33 & 1.33 & 0.00 & 0.00 & 3.33 & 0.00 & 2.00 \\
5 & 5 & 1.60 & 0.80 & 0.80 & 1.60 & 1.60 & 0.00 & 2.00 \\
6 & 4 & 2.50 & 0.50 & 1.00 & 0.50 & 1.00 & 1.50 & 2.00 \\
7 & 4 & 2.50 & 2.50 & 0.50 & 0.50 & 1.00 & 1.00 & 1.00 \\
8 & 2 & 2.00 & 2.00 & 5.00 & 5.00 & 0.00 & 0.00 & 2.00 \\
9 & 3 & 0.67 & 1.33 & 2.67 & 3.33 & 0.00 & 1.33 & 2.67 \\
10 & 4 & 2.00 & 0.00 & 1.50 & 2.00 & 1.50 & 1.00 & 2.50 \\
11 & 2 & 3.00 & 2.00 & 0.00 & 2.00 & 0.00 & 5.00 & 2.00 \\
$:$ & $:$ & $:$ & $:$ & $:$ & $:$ & $:$ & $:$ & $:$ \\
39 & 2 & 0.00 & 0.00 & 0.00 & 3.00 & 0.00 & 5.00 & 0.00 \\
\hline & $\mathbf{S j}$ & $\mathbf{2 0 . 1 0}$ & $\mathbf{1 6 . 9 7}$ & $\mathbf{1 7 . 1 3}$ & $\mathbf{2 2 . 4 3}$ & $\mathbf{1 3 . 4 3}$ & $\mathbf{1 4 . 8 3}$ & $\mathbf{2 0 . 1 7}$ \\
& $\mathbf{F j}$ & $\mathbf{3 2}$ & $\mathbf{3 2}$ & $\mathbf{2 3}$ & $\mathbf{2 2}$ & $\mathbf{2 5}$ & $\mathbf{2 3}$ & $\mathbf{3 5}$ \\
\hline
\end{tabular}

Tabel 7. Hasil Perkalian Bobot dengan Hasil WAQ

\begin{tabular}{ccccccccc}
\hline No. & $\begin{array}{c}\text { Rata- } \\
\text { Rata } \\
\text { Jawaban }\end{array}$ & $\mathbf{O}$ & $\mathbf{I}$ & $\mathbf{D}$ & $\mathbf{M}$ & $\mathbf{T}$ & $\mathbf{P}$ & $\mathbf{W}$ \\
\hline $\mathbf{1}$ & 0.50 & 1.25 & 1.25 & 0.5 & 0.25 & 0.5 & 0 & 1 \\
$\mathbf{2}$ & 0.33 & 0.33 & 1.67 & 0.67 & 0.67 & 1.67 & 0.00 & 0.00 \\
$\mathbf{3}$ & 0.67 & 0.67 & 0.33 & 1.67 & 1.33 & 0.33 & 0.00 & 1.00 \\
$\mathbf{4}$ & 0.17 & 0.67 & 0.67 & 0.00 & 0.00 & 1.67 & 0.00 & 1.00 \\
$\mathbf{5}$ & 0.83 & 0.80 & 0.40 & 0.40 & 0.80 & 0.80 & 0.00 & 1.00 \\
$\mathbf{6}$ & 0.33 & 1.25 & 0.25 & 0.50 & 0.25 & 0.50 & 0.75 & 1.00 \\
$\mathbf{7}$ & 0.33 & 1.25 & 1.25 & 0.25 & 0.25 & 0.50 & 0.50 & 0.50 \\
$\mathbf{8}$ & 0.17 & 1.00 & 1.00 & 2.50 & 2.50 & 0.00 & 0.00 & 1.00 \\
$\mathbf{9}$ & 0.33 & 0.33 & 0.67 & 1.33 & 1.67 & 0.00 & 0.67 & 1.33 \\
$\mathbf{1 0}$ & 0.67 & 1.00 & 0.00 & 0.75 & 1.00 & 0.75 & 0.50 & 1.25 \\
$\mathbf{1 1}$ & 0.17 & 1.50 & 1.00 & 0.00 & 1.00 & 0.00 & 2.50 & 1.00 \\
$\mathbf{:}$ & $:$ & $:$ & $:$ & $:$ & $:$ & $:$ & $:$ & $:$ \\
$\mathbf{3 9}$ & 0.17 & 0.00 & 0.00 & 0.00 & 1.50 & 0.00 & 2.50 & 0.00 \\
\hline & $\mathbf{s j}$ & $\mathbf{1 0 . 0 5}$ & $\mathbf{8 . 4 8}$ & $\mathbf{8 . 5 7}$ & $\mathbf{1 1 . 2 2}$ & $\mathbf{6 . 7 2}$ & $\mathbf{7 . 4 2}$ & $\mathbf{1 0 . 0 8}$ \\
& $\mathbf{f j}$ & $\mathbf{2 7}$ & $\mathbf{3 0}$ & $\mathbf{2 0}$ & $\mathbf{2 1}$ & $\mathbf{2 4}$ & $\mathbf{2 2}$ & $\mathbf{3 1}$ \\
\hline
\end{tabular}

Tabel 8 menunjukkan peringkat waste dalam proses produksi ban PSR. Tiga Waste kritis yang terdeteksi dari hasil Waste Assessment Model adalah waste Waiting, Motion, dan Overproduction. Hasil perhitungan dengan menggunakan WAQ selaras dengan hasil identifikasi waste dengan metode PAM, yaitu proporsi waste terbesar teridentifikasi berasal dari waste delay. Hal ini berbeda dengan penelitian (Chrisna \& Ahmad, 2018), yang memperoleh hasil assessment waste untuk perusahaan otomotif dengan persentase terbesar terdapat pada waste defect, motion, dan waiting. Sedangkan (Isnain, 2017) menggunakan Bourda Count Method untuk mengidentifikasi waste kritis di industri otomotif mobil sedan menyatakan bahwa waste kritis 
teridentifikasi dengan proporsi terbesar adalah waste waiting dan waste defects. Hal ini menunjukkan bahwa rata-rata identifikasi waste dalam dunia industri otomotif terjadi pada waste waiting dan defects.

Tabel 8. Hasil akhir Waste Assessment Questionnaire

\begin{tabular}{lccccccc}
\hline & $\mathbf{O}$ & $\mathbf{I}$ & $\mathbf{D}$ & $\mathbf{M}$ & $\mathbf{T}$ & $\mathbf{P}$ & $\mathbf{W}$ \\
\hline Skor (Yj) & 0.42 & 0.47 & 0.43 & 0.48 & 0.48 & 0.48 & 0.44 \\
$\begin{array}{l}\text { Pj Factor } \\
\text { Final }\end{array}$ & 1368 & 1080 & 1024 & 1368 & 816 & 448 & 1764 \\
$\begin{array}{l}\text { Result } \\
\text { (Yj Final) }\end{array}$ & 577.1 & 506.2 & 445.2 & 652.9 & 391.6 & 214.2 & 781.2 \\
Persentase & 0.16 & 0.14 & 0.12 & 0.18 & 0.11 & 0.06 & 0.22 \\
\hline Rank & $\mathbf{3}$ & $\mathbf{4}$ & $\mathbf{5}$ & $\mathbf{2}$ & $\mathbf{6}$ & $\mathbf{7}$ & $\mathbf{1}$ \\
\hline
\end{tabular}

\section{Identifikasi Penyebab Waste}

Berdasarkan hasil dari identifikasi waste yang dilakukan menggunakan PAM dapat dilihat bahwa waste paling banyak terjadi pada lantai produksi pembuatan ban PSR adalah waste delay. Waktu waste terbesar adalah pada workstation curing dengan penyebab utama yaitu adanya setup yang lama pada mesin curing. Salah satu tools yang dapat digunakan untuk menganalisis akar masalah adalah dengan manggunakan Fishbone chart. Fishbone chart dapat digunakan untuk mengidentifikasi penyebab lamanya waktu setup pada workstation curing berdasarkan man, machine, method, material, dan environment (Carmona \& Sieh, 2004). Pembuatan fishbone didapatkan dengan melakukan observasi langsung pada workstation curing pembuatan ban PSR.

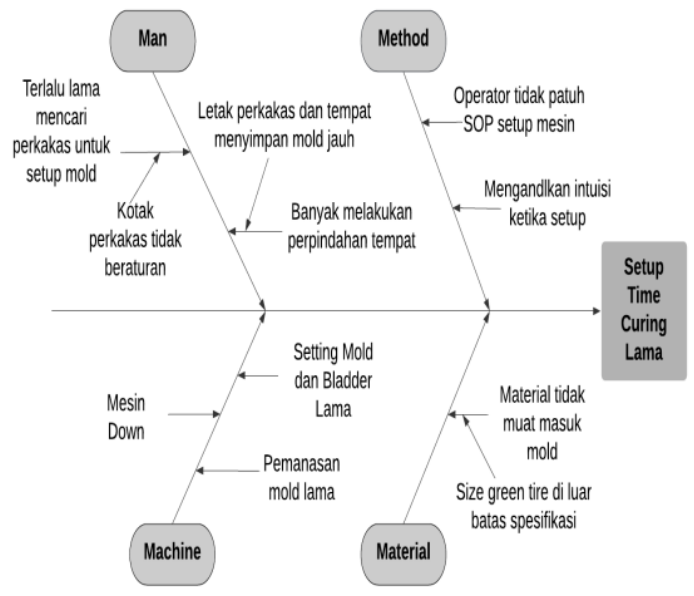

\section{Gambar 3. Fishbone Chart Setup Time Curing}

Fishbone chart yang memiliki empat faktor yaitu man, methode, machine, dan material (Gambar 3). Keempat faktor ini berpengaruh terhadap lamanya setup curing. Man atau operator yang menjalankan setup mesin curing sangat berpengaruh terhadap lamanya waktu setup. Beberapa gerakan operator yang berpengaruh terhadap lamanya waktu setup adalah gerakan mencari perkakas untuk melepas baut dan gerakan perpindahan tempat untuk mengambil atau menyimpan bladder dan mold. Hal ini menyebabkan banyak waktu yang terbuang dan bukan proses value added bagi produk.

Faktor yang berpengaruh pada method adalah setiap operator memiliki caranya masingmasing di dalam proses setup mesin curing. Tidak ada standard kerja maupun checklist urutan proses setup yang ditetapkan. Sehingga banyak operator yang mengulangi gerakannya untuk mengambil sesuatu atau untuk menyimpan sesuatu. Selain itu operator banyak yang tidak mengerti tentang internal setup dan eksternal setup. Aktivitas setup hampir semuanya dilakukan ketika mesin mati (internal setup).

Faktor yang cukup berpengaruh dalam setup mesin adalah mesin curing itu sendiri. Ketika sedang berlangsung proses setup mesin terkadang tiba-tiba mesin down karena domp pack bocor atau bladder bocor. Selain itu, pemasangan mold dan bladder cukup lama karena mold sendiri memiliki berat $50 \mathrm{Kg}$ sehingga ketika memasang atau melepasnya harus menggunakan forklift.

Tabel 9. Akar Permasalahan 5 Whys

\begin{tabular}{|c|c|c|c|c|}
\hline Cause & Sub cause & Why & Why & Why \\
\hline \multirow[t]{2}{*}{ Man } & $\begin{array}{l}\text { Terlalu lama } \\
\text { mencari } \\
\text { perkakas } \\
\text { untuk setup } \\
\text { mold }\end{array}$ & $\begin{array}{l}\text { Kotak } \\
\text { perkakas } \\
\text { berantakan }\end{array}$ & $\begin{array}{l}\text { operator } \\
\text { meletakkan } \\
\text { perkakas } \\
\text { sembarangan }\end{array}$ & $\begin{array}{l}\text { tidak ada } \\
\text { aturan } \\
\text { peyimpanan } \\
\text { perkakas }\end{array}$ \\
\hline & $\begin{array}{l}\text { operator } \\
\text { banyak } \\
\text { melakukan } \\
\text { perpindahan } \\
\text { tempat ketika } \\
\text { setup }\end{array}$ & $\begin{array}{l}\text { mold, bladder, } \\
\text { kotak } \\
\text { perkakas, dan } \\
\text { green tire } \\
\text { disimpan di } \\
\text { area yang } \\
\text { berbeda }\end{array}$ & $\begin{array}{l}\text { Area } \\
\text { penyimpanan } \\
\text { (tool storage) } \\
\text { memiliki tempat } \\
\text { tersendiri }\end{array}$ & \\
\hline Method & $\begin{array}{l}\text { operator } \\
\text { memiliki cara } \\
\text { yang } \\
\text { berbeda } \\
\text { dalam setup }\end{array}$ & $\begin{array}{l}\text { Tidak ada } \\
\text { checklist } \\
\text { urutan setup }\end{array}$ & $\begin{array}{l}\text { standardisasi } \\
\text { kerja dalam } \\
\text { setup belum } \\
\text { ditentukan }\end{array}$ & \\
\hline \multirow[t]{3}{*}{ Machine } & Mesin down & $\begin{array}{l}\text { Domp pack } \\
\text { bocor }\end{array}$ & $\begin{array}{l}\text { mesin terlalu } \\
\text { panas atau } \\
\text { terlalu lama } \\
\text { digunakan }\end{array}$ & $\begin{array}{l}\text { Produksi per } \\
\text { batch } \\
\text { melebihi } \\
\text { kapasitas } \\
\text { mesin per } \\
\text { hari }\end{array}$ \\
\hline & $\begin{array}{l}\text { pemanasan } \\
\text { molding lama }\end{array}$ & $\begin{array}{l}\text { Mesin curing } \\
\text { membutuhkan } \\
\text { waktu } 30 \text { menit } \\
\text { untuk } \\
\text { pemanasan } \\
\text { mold }\end{array}$ & & \\
\hline & $\begin{array}{l}\text { setting } \\
\text { bladder dan } \\
\text { mold lama }\end{array}$ & $\begin{array}{l}\text { pemasangan } \\
\text { baut lama }\end{array}$ & $\begin{array}{l}\text { dilakukan } \\
\text { penyetelan } \\
\text { spanner yang } \\
\text { berbeda-beda }\end{array}$ & $\begin{array}{l}\text { model baut } \\
\text { berbeda- } \\
\text { beda }\end{array}$ \\
\hline Material & $\begin{array}{l}\text { material tidak } \\
\text { muat masuk } \\
\text { mold }\end{array}$ & $\begin{array}{l}\text { green tire } \\
\text { oversize }\end{array}$ & $\begin{array}{l}\text { luput dari } \\
\text { inspeksi }\end{array}$ & \\
\hline
\end{tabular}


Material berupa green tire cacat yang telah sampai pada WIP curing terkadang lolos dari inspeksi. Defect pada green tire berupa lapisan dalam robek atau terdapat benjolan terkadang baru ditemukan ketika operator curing sedang menyemprotkan silicon (GOP dan GIP) pada green tire. Terkadang terdapat green tire yang oversize sehingga ketika akan dimasukkan kedalam mold maka ukuran mold tidak sesuai dengan green tire.

Akar permasalahan dapat diperoleh dengan menggunakan metode 5 whys yaitu alat bantu (tool) root cause analysis untuk problem solving. Tools ini membantu mengidentifikasi akar masalah atau penyebab dari ketidaksesuaian pada proses atau produk (Gangidi, 2019). Akar permasalahan akan didapatkan secara terus bertanya mengapa (biasanya 5 kali) dan dapat dimengerti dengan baik.

Pada Tabel 9 menjelaskan permasalahan yang terjadi pada pada workstation curing yang menjadi penyebab lamanya waktu setup. Akar masalah yang menjadi penyebab lamanya waktu setup adalah kelengahan operator dalam menata perkakas, dan tidak ada standarisasi kerja seperti urutan checklist setup curing dan standard penyimpanan perkakas. Setelah mengetahui akar permasalahan yang terjadi langkah selanjutnya adalah menentukan metode atau tools yang dapat digunakan untuk meminimasi waktu setup curing.

\section{KESIMPULAN}

Process activity mapping menunjukkan $52 \%$ dari lini produksi pembuatan ban PSR merupakan aktivitas yang value added (memberikan nilai tambah). Aktivitas non value added terbesar adalah delay (1060 detik) dan transportation (923 detik). Tiga waste kritis yang terdeteksi dari hasil Waste Assessment Model adalah waste Waiting, Motion, dan Overproduction dengan persentase masing-masing waste yaitu $22 \%, 18 \%$, dan $16 \%$. Hal ini selaras dengan hasil identifikasi waste dengan metode PAM, yaitu proporsi waste terbesar teridentifikasi berasal dari waste delay. Kontribusi terbesar atas adanya waste delay dan waste waiting dengan menggunakan fishbone adalah permasalahan setting mesin pada workstation curing. Penelitian ini belum dilakukan tahap usulan perbaikan terhadap waste yang teridentifikasi sehingga untuk penelitian selanjutnya dapat dilakukan perbaikan pada waste waiting yang berkontribusi waste terbesar yang terjadi pada workstation curing.

\section{DAFTAR PUSTAKA}

Ali, B., Jaweed, S., \& Fahad, M. (2015). Implementation of waste assessment matrix and line balancing for productivity improvement in a high variety/high volume manufacturing plant. Proceedings of ESMD, Karachi,

$65-75$.

https://www.researchgate.net/publication/29 5806964

Amrina, E., \& Lubis, A. A. A. (2017). Minimizing waste using lean manufacturing: $A$ case in cement production. 2017 4th International Conference on Industrial Engineering and Applications (ICIEA), 71-75. https://doi.org/10.1109/IEA.2017.7939181

Carmona, M., \& Sieh, L. (2004). Measuring Quality in Planning: Managing the Performance Process. Taylor \& Francis. https://books.google.co.id/books?id=8qKW RpG57isC

Chrisna, C., \& Ahmad, A. (2018). Pemetaan Pemborosan (Waste) Dalam Proses Produksi Pada Seksi Painting Plastic (Studi Kasus Perusahaan Otomotif). Jurnal Teknik Industri, 8(3), 201-212. https://www.trijurnal.lemlit.trisakti.ac.id/tekin/ article/view/4734

Frandson, A., \& Tommelein, I. D. (2014). Development of a Takt-time Plan: A Case Study. Construction Research Congress 2014, 1646-1655. https://doi.org/doi:10.1061/9780784413517. 168

Gangidi, P. (2019). A systematic approach to root cause analysis using $3 \times 5$ why's technique. International Journal of Lean Six Sigma, 10(1), 295-310. https://doi.org/10.1108/IJLSS-10-2017-0114

Isnain, S. K. (2017). Perancangan perbaikan proses produksi bodi mobil Daihatsu Xenia dengan lean manufacturing di PT. Inti Pantja Press Industri. Skripsi. Institut Teknologi Sepuluh Nopember. https://repository.its.ac.id/2609/

Jasti, N. V. K., \& Sharma, A. (2014). Lean manufacturing implementation using value stream mapping as a tool. International Journal of Lean Six Sigma, 5(1), 89-116. https://doi.org/10.1108/IJLSS-04-2012-0002

Jeyaraj, A., Sauter, V. L., \& St, M. (2014). Validation of business process models using swimlane diagrams. Journal of Information Technology Management, 25(4), 27-37. https://jitm.ubalt.edu/XXV-4/article3.pdf

Linck, J., \& Cochran, D. S. (1999). The Importance of Takt Time in Manufacturing System Design. In SAE Technical Paper (pp. 1-8). SAE Technical Paper. https://doi.org/10.4271/1999-01-1635

Martha, K. E., \& Arvianto, A. (2018). Analisis Identifikasi Penyebab Terjadi Rendahnya 
Functuality Achievement Dengan Mengunakan Toyota Business Practice (Studi Kasus: PT. Toyota Motor Manufacturing Indonesia). Industrial Engineering Online Journal, 7(3), 1-8. https://ejournal3.undip.ac.id/index.php/ieoj/a rticle/view/22446

Pomalia, F., Iftadi, I., \& Astuti, R. D. (2020). Waste analysis of fuselage assembly in panelization group of the 117th NC212i aircraft . Jurnal Sistem Dan Manajemen Industri, $\quad 4(1), \quad 61-71$. https://doi.org/10.30656/jsmi.v4i1.2187

Rawabdeh, I. A. (2005). A model for the assessment of waste in job shop environments. International Journal of Operations \& Production Management,
25(8),

800-822.

https://doi.org/10.1108/0144357051060861 9

Robecca, J., Made Aryantha Anthara, I., Silaban, M., \& Situmorang, M. R. (2020). Product Quality Improvement by Using the Waste Assessment Model and Kipling Method. IOP Conference Series: Materials Science and Engineering, $\quad 879(1), \quad 12172$. https://doi.org/10.1088/1757899x/879/1/012172

Taylor, D., \& Hines, P. (2000). Going Lean: A Guide to Implementation. Lean Enterprise Research Centre. https://books.google.co.id/books?id=4BBkA AAACAAJ 